\title{
THEOLOGY OF AIDS: A LUTHERAN/MORAVIAN CASE STUDY
}

Klaus Nürnberger

University of Natal

\begin{abstract}
This essay offers a critical introduction to the Lutheran/Moravian programme to combat the HIV/AIDS pandemic, drafted in March 2000, which has not been exposed to public debate as yet. It includes deep going theological reflection as well as a concrete plan of action: The law of God formulates the preconditions for a healthy human existence as revealed by observation and reason, rather than an authoritarian code of conduct. The gospel of Christ, understood as God's suffering, transforming acceptance of the unacceptable makes us ready to bear the cross with those who are infected and affected. The prophetic ministry has to focus on exposing and overcoming the hedonistic assumption of the modern commercial culture. The plan of action focuses on the establishment of AIDS Committees in each parish, which spread information, identify cases, and establish a local AIDS Support Group for each patient, based on the extended family and a caring community. Unwieldy and expensive bureaucracies are discouraged.
\end{abstract}

\section{The Lutheran/Moravian programme to combat the HIV/AIDS pandemic} "Theology of AIDS" - what a monstrous idea! HIV/AIDS is too serious a problem to theologise about. People are dying and what is needed is action! Fair enough, but action needs to be grounded in the depths of communal convictions and commitments, otherwise it will not happen, or if it happens, it may lack direction and determination. Perhaps we have had not too much but too little profound theologising about the crisis!

Recent statements by the Catholic and the Anglican Churches on HIV/AIDS have attracted a lot of publicity. ${ }^{1}$ In contrast, the earlier initiative of the Lutheran Communion in Southern Africa (a loose federation of Lutheran and Moravian churches on the sub-continent) has not become known. This essay gives a critical introduction to the basic document, called The Church and AIDS: Proposed Programme for the Lutheran and Moravian Churches in Southern Africa to respond to the HIV/AIDS crisis. It was drawn up in March 2000 and contains both profound theological reflection and a workable plan of action.

LUCSA acknowledges the fact that material on the pandemic is not in short supply and that ecumenical cooperation is essential. Its motivation to draw up its own document is twofold:

to implement a programme successfully we must take our own initiatives ... based on our own theological tradition, channeled through our own church structures and meant to take root in our own congregations

and

we also believe that we can contribute our own insights to the wider church and the society at large.

1. See sources in Note 8 below. 


\section{Introducing the subject}

The main issues caused by the disease are enumerated: changing collective attitudes, embarking on concrete measures to prevent infection, and coping with the infection and the disease itself. Under the latter heading the following issues are mentioned:

- How to deal with the HIV infection before the onset of AIDS.

- How to cope with the psychological trauma connected first with the infection and then with the disease itself.

- How to heal disturbed human relationships in the family, the community, the work place, such as stigma, ostracism, discrimination, and rejection.

- How to accompany the infected during the active stages of the disease.

- How to accompany family members and others who are affected by an AIDS case.

- How to assist the orphaned and widowed.

- How to deal with the economic consequences of AIDS in terms of family finance, the brain drain in the private sector, state resources, and the national economy as a whole.

- How to deal with the physical, psychological and educational needs of a young generation whose parents have been eliminated.

Because the document was designed to help local communities to respond to the disease in a practical way, it did not deal with the larger social consequences of the pandemic to a sufficient extent: the dramatic decline in the economically active population; the resultant drop in Gross Domestic Product; the immense medical, legal and funeral costs; the cultural anomie and social instability caused by impoverished families, masses of orphaned children, traumatised youth and uncared-for elderly; the escalation of prostitution as a last resort; the growth of the street children population; the dearth of teachers, police and competent administrators, and so on. ${ }^{2}$

The document does not stop with practical tasks, but goes on to enumerate the spiritual challenges and opportunities posed by the disease. Under "challenges" the question is asked why the problem has been ignored or avoided so far by the churches and enumerates possibilities for reflection.

Was it ignorance? Was it fear that the problem would swamp us? Was it the belief that the problem does not exist within the church? Was it due to judgmental attitudes ("It serves them right!")? Was it a feeling of helplessness and hopelessness? Was it due to an over-spiritualised gospel? Did we believe that, once we are saved, diseases could no longer attack us? Did we believe that the church was not competent or called upon to deal with public concerns such as health, and that such issues should be left to social workers, hospitals, or the state? Did we ignore the fact that the mission of Jesus was directed overwhelmingly to sick people, sinners and outcasts? Was it a general unwillingness to get involved in human suffering, or to carry the cross of Christ for the sake of others?

Cultural taboos on speaking about sex, the stigma attached to the disease because it is sex-related and the right to secrecy is are probably more important than all those

2. A summary of these factors is found in a statement made by Peter Piot, UNAIDS Executive Director at the United Nations University in Tokyo on the 2 October 2001. Source: "e-Praxis"<teologie@ bigfoot.com> 10/8/2001. See also Rob Garner and Robyn Hemmens in YFC KwaZulu-Natal Sept 2001 issue, p 3ff. For a detailed economic assessment see The SA Journal of Economics Vol 68:5 / Dec 2000, Special Issue on Economics of HIV/AIDS. 
mentioned. But then, in spite of being "a horrific calamity", the disease also poses opportunities to rediscover the relevance and the power of the Christian faith. The following questions call for reflection and debate in conscientisation workshops:

How can we regain a sense of the deeper meaning of sexuality? How can we regain a sense of the importance of healthy marriages and family structures? How can we use the gospel of salvation by grace rather than by achievement to neutralise ill-advised peer pressure and to channel peer support in the right direction? How can we deal with counterproductive assumptions and values, such as sex as a symbol of male virility, patriarchy and female dependency? How can we deal with superstitions, such as the idea that intercourse with a virgin can cure the disease? How can we cope in a case where "technological fixes" no longer work? How can we deal with the failure of individualised human rights, in this case the ostensible rights to unlimited sexual gratification and privacy? How can we overcome the spiritualisation and abstraction of the gospel from concrete life? How can we make law and gospel relevant to youths who are groping for their own identity, reject adult authority, believe that dangerous living is smart, experiment with drugs and sex, and are subject to peer pressure? How can Sunday morning congregations be transformed into caring communities which take up the needs of their members, as some African Initiated Churches do? How can we deal with the failure of the modern hedonistic ideology and culture, according to which pleasure, utility and profit are the prime values?

AIDS presents us with an opportunity to make an indispensable, specifically spiritual contribution to a secular society which believes it can do without religion. It is also an opportunity to make our theoretical faith real in a holistic and practical way.

\section{Reflections on what Lutherans believe}

We all base our convictions on the biblical witness culminating in the redeeming gospel of Christ. But there are certain emphases and interpretations which are more pronounced in Lutheranism than in other traditions.

\section{God is in control}

This faith in God's mastery over the universe is important because it helps us to see that our own little lives are part of God's creation as a whole and that this creation is highly ambiguous. It is wonderful and terrible at the same time. In modern times we tend to think that humans are responsible for everything that happens in the world, and that through science and technology we can understand and fix all problems. The book of Job tells us that the world which God created is much larger and much more complicated than we can ever imagine.

Not every calamity is due to human failure, and not every calamity can be overcome through human effort. The existence of the HIV virus, the floods in Mozambique, or great social upheavals such as the Second World War is cases in point. Humans depend on much greater forces and can become victims of such greater forces. The gift of the biblical faith is that we can appeal to a personal God who is in charge of these powers. He can transform chaos into order, prevent catastrophes for life to flourish, turn sin into blessing. This is a source of great comfort. But it is also a source of great agony. If God is in charge, why does he allow the war in Central Africa, the floods in Mozambique, or the AIDS pandemic to happen? Why must all living creatures suffer and die? Why does he not prevent humans from taking the wrong decisions? Our experiences in the world do not suggest that a 
powerful and loving God is in control of the world. Either he has power but no love, or he has love but no power. This agony is unavoidable; it is also the root of committed faith.

Luther says that, in creation, we experience only the fearful power and majesty of God, but not his love. If we want to discover God's true intentions we must look at the cross of Christ. Here a terrible human catastrophe is proclaimed to be God's act of salvation. If he can turn such a disaster into his prime tool of redemption, then he can also turn our own disasters into tools of redemption...

Faith is a stubborn refusal to succumb to hopelessness, despondency and fatalism. Faith is trust in the love of God in the face of all the calamities we experience. Faith appeals to the God of mercy against the same God who seemingly wants to destroy us. Faith struggles with God for his protection and blessing as Jacob did at the Jabbok. Even Jesus struggled with God in Gethsemane, sweating blood, until he understood that what was going to happen was part of God's redemptive will. We need this faith; otherwise we may be overwhelmed by the onslaught of the AIDS pandemic.

God's will: the well-being of his creatures

In an emancipatory age there are two typical reactions to what is called the "law of God" or "the commandments" in theology. Either one falls into reactionary legalism, insisting that the will of God has been revealed as a clear set of instructions and prohibitions, which are to be kept to the letter regardless of the consequences. Or one protests human autonomy against the authoritarianism and prudishness of biblical and ecclesial injunctions and ends up in a libertinism where everything goes. The document draws on Luther's insight that the concrete contents of ethical behaviour must be based on observation and reason, not on revelation.

The basic rationale of the law is to expose and prevent evil. When we speak of the law of God we must abandon the idea that it is a set of arbitrary and oppressive rules laid down by a tyrannical dictator in heaven, who will mercilessly punish any insubordination regardless of whether the law makes sense or not. Modern humans ... want to see for themselves, think for themselves, take their own decisions, pursue their own interests. It is more important now than ever before to emphasise with Paul (Gal 3 and 4) that we are not meant to be slaves or babies but mature and responsible sons and daughters of God. The law of God presupposes freedom and responsibility, not slavish submission.

The law is a formulation of what is needed for a healthy and fulfilled human life - a life in peace with God, with our community and with the rest of creation. The God of love wants us to survive and prosper. As situations change, God grants us ever-new insights into what is dangerous and what is profitable. Luther said we must "write ever new decalogues". The problem of HIV/AIDS is a case in point. It is a new disease, but we already know a lot about how it works and how it is transmitted. Scientists agree that it could be brought under control by following a few simple rules:

- Life long single partner sexual relationships.

- Sexual abstinence of the infected.

- No pregnancies of infected women.

- No drug abuse.

- No transfusion of infected blood.

- Protection of health workers and carers against infection.

- A life style which builds up and maintains the immune system: proper nutrition, exercise, moderate stress levels, absence of disease overload, etc. 
The documents also states three more lenient and less effective rules: (a) no sexual intercourse between infected and uninfected partners without condoms, (b) no anal intercourse, because the latter increases the risk of infection, and (c) no needles for the injection of drugs which have been used before!

These rules are not based on prudishness or divine revelation but on necessity. We are confronted with a crisis of immense proportions which must be overcome. The rules are also very simple. No superhuman powers are needed, only responsibility and self-discipline. Assuming that all information has been made available, the society can expect its members to desist from detrimental attitudes, actions and relationships.

The society also has the right and the duty to take appropriate measures to protect itself and its members against those who will not heed these expectations. According to the Bible and Lutheran theology, such measures can be harsh if needed be. The society should say in no uncertain terms that it will not tolerate a kind of behaviour which endangers human well-being. Where the capacity of individuals to resist evil is overtaxed, we need appropriate social sanctions, support groups, a legal system and law enforcement agencies. We also need the transformation of our values and motivations to fortify our defences against temptations and rationalisations. That is the law of God.

What is remarkable about these formulations is their pragmatism. You do not teach something because it is written in the Bible or part of an ecclesial tradition, but realise that an injunction is written in the Bible because, at the time of writing, it was believed to be in line with God's vision of comprehensive human well-being. The document does not insist, for instance, on abstinence outside the marriage bond or prohibit, as a matter of principle, the use of condoms. It simply formulates essential facets of behaviour if we are serious in trying to overcome the pandemic. And they do so in no uncertain terms. As we shall see below, on other grounds and in wider contexts Lutherans also stand for chastity outside marriage.

Pragmatic - yes! Simple - yes! Easy to implement - no! It is the character of fundamental prerequisites of a healthy society that they are simple yet beset with a myriad obstacles and complications when it comes their implementation. Basic demands of well-being challenge us not to be impressed by such difficulties but to go forward in faith and overcome the obstacles. If we want life, we have to stop killing each other - it is as simple as that. It is astounding to see that academics and public figures hardly ever dare to lay their fingers on the most basic and the simplest prerequisites for the prevention of the disease.

\section{The Gospel: God's suffering acceptance of the unacceptable}

Lutherans have often been accused - and not always without justification - that they tear apart the law of God and the gospel of grace. The document does not fall into this trap:

The gospel does not introduce a new principle into the picture. In the gospel of grace the same God speaks to us who is determined to bring about our well-being. But while the law is meant to prevent evil, the gospel responds to an evil which has already come about. If one condemns and ostracises somebody infected with HIV on the basis of the law of God, one only increases the calamity. Judgment and condemnation do nothing to help the person and the community to get out of the predicament. According to Paul, the law is good at exposing evil, but it cannot redeem.

The gospel responds to evil in a creative and redemptive way. It says that God accepts us into his fellowship, not because we are acceptable, but in spite of the fact that we are not acceptable. The father of the prodigal son does not expect the son to return the lost property, get washed and dressed decently and mend his ways before 
accepting him into his fellowship. Instead he calls a festival to celebrate the restored fellowship.

The evil which is unacceptable should not be seen only in moral terms. It does not matter whether we are unacceptable because of our moral failures, our lack of understanding, our diseased bodies, our broken relationships, or our mortal bodies. God suffers the fact that we are in an unacceptable state, regardless of the causes. This is important in the case of AIDS, where all these factors interact to compound the problem.

The motive for God's suffering acceptance is not to condone evil but to overcome evil. It is the fellowship of God itself out of which redeeming power flows. It is the acceptance of the father, which changes the life of the prodigal son. Transformation is not the condition of acceptance, but it is indeed the consequence. God expects us to get healed in his fellowship. Luther said, with Jesus, that from a good tree good fruits will follow. We have said that God uses human observation and reason to formulate the law. He also uses human motivations to accept the unacceptable for the sake of redemption. The community of those who have been accepted by God is used by God to accept others. If God has accepted us into his fellowship without condition, willingly suffering under our unacceptable condition, we cannot now set conditions for accepting each other in this same fellowship. We have to suffer each other as God has suffered us.

Here we can learn from the African concept of ubuntu: a person remains a person, as long as he/she is embedded in the solidarity of the community, regardless of his/her condition, situation or performance. Similarly Luther distinguished between the person and his work; God hates sin but loves the sinner. God's acceptance of the unacceptable means that God suffers. That is what the cross of Christ is all about. When we become God's instruments of acceptance and transformation, we will share God's suffering. It is the elder brother of the prodigal son who is unwilling to share the suffering acceptance of his father. Now he, not his brother, was "lost" to the Father.

It has often been said that the worst consequences of infection are the stigmatisation, isolation, discrimination, ostracism and rejection of the infected and affected by the family, the community, the employees, the colleagues and the society at large. This leads to shame, guilt feelings, self-hatred, fear, anxiety, secrecy, denial, loneliness, loss of beloved ones, and so on. This scourge cannot be overcome through trivialising or playing down moral responsibility for the consequences of unacceptable behaviour, but only by the unconditional suffering acceptance of the unacceptable whether it is the unacceptability of sin, or the unacceptability of disease and death. The infected are embedded in a community of forgiven sinners, who are all vulnerable to temptation, misfortune, loss of dignity, the ravages of crippling diseases and death.

We should not play down the extent of the suffering that the presence and the demands of AIDS patients among us will entail. It can become costly and quite devastating for the family and the community. The cross cannot be taken lightly. But it is not something abnormal for Christians to suffer for the sake of others. Christians share in the death of the crucified Christ, so that they might also share in the new life of Christ. Being called to suffer for the sake of others cannot surprise or antagonise Christians. It is their very lifeblood.

Again all this sounds simple. Of course it is not. Taboos against deadly diseases are not irrational. They are part of our instincts, ingrained in us through millennia of evolutionary experience. In this particular case we are most fortunate that the transmission of the HIV virus is restricted to certain media which can be avoided. It also takes time to develop into 
full-blown AIDS. It is also possible to adjust one's life style, use retroviral drugs and add healthy years to one's life. ${ }^{3}$ So we must do our best to dismantle taboos, prejudices and discrimination and help our compatriots to regain and maintain social esteem and quality of life.

But the HIV virus is known to be extremely versatile. It churns out ever-new mutations in rapid succession. Just imagine what would happen if it produced a variety which could be transmitted through the air we breathe! We could catch it as we catch a cold when somebody coughs in a lift. By way of comparison, consider the extreme transferability and lethality of the Ebola virus. To care for such patients is, virtually, a death sentence. William Clark calls it "the worst possible nightmare". If we ever reached that stage we would be in real trouble. ${ }^{4}$ Shall our human rights culture then still prohibit compulsory testing? Will it still be a non-notifiable disease? ? $^{5}$ Shall we then still be able to chide our contemporaries for avoiding contact, marginalising the infected, casting a taboo on social intercourse? Unconditional acceptance is a great word, but it can be an extremely costly practice. It cost Christ, our Lord, his life!

\section{The fruits of the Gospel: Transformation}

Lutherans have also been accused of moral carelessness stemming from a conception of "cheap grace" - again not always without justification. Again the document does not fall into this trap. It distinguishes between personal renewal and societal transformation:

Suffering acceptance leads to transformation. Not only the infected persons themselves but, together with them, the affected families, the congregation, and the community as a whole enter into a process in which they are transformed into a responsible, accepting, coping, caring, supporting community ... The infected and the affected become witnesses and instruments of God's redeeming action by coming forward, warning others, coping and caring.

Transformation is always a process which has to face obstacles and backlashes and which has to be embarked upon consciously and with determination. According to Luther's theology, a Christian is justified and a sinner at the same time. This means that the unacceptable old attitudes and patterns of behaviour are overcome progressively by the new life of Christ in the power of the Holy Spirit. Baptism means that "the old Adam is drowned every day and arises into a new life" - the life of the risen Christ. However, our participation in God's acceptance and transformation also has its limits. We can comfort the afflicted, care for the suffering, and restore human relationships. But so far we have no cure for AIDS. Confronted with this devastating condition, our efforts will remain hopelessly inadequate. But believers refuse to accept that their limits are also the limits of their God. That is where Christian hope comes into the picture. Christians will go as far as their powers allow, but they will also reach out beyond these powers to the power of God... If God is God, death and destruction cannot have the last word.

3. The Enthembeni care centre of Lana Oatway near Richard's Bay is an example of a success story in this regard. The Natal Witness, 4 Oct 2001, p 15.

4. WR Clark 1995. At war within: The double-edged sword of immunity. New York / Oxford: Oxford Univ Press, p 170).

5. For the legal position and a code of conduct at the work place see Government Gazette No 21815 / 1-12-2000 (www.labour.gov.za). 
Public responsibility

Concerning societal transformation the document has this to say:

Lutheran theology has never restricted Christian vision to the community of believers. God is not only the Lord of the church, but also the Lord of the world. Christians are not only members of the church, but also citizens of the state. God's redemptive intentions are valid as much for society at large as they are valid for the community of believers. That is what our tradition of the two reigns of God is all about.

Luther distinguished between God's redemptive action in our hearts on the one hand and in the structures of society on the other. In our hearts he exposes and overcomes evil through the law and the gospel, which are proclaimed by preachers and lived out by the community of believers. This is the reign of God on the right ...

In society he exposes and overcomes evil through the structures of society, which are administered by offices and upheld by all citizens. This is the reign of God on the left. It includes the state, the legal system, the economy, public health services, the educational system, civil organisations, and so on. The two dimensions are meant to interact with each other. Society needs spiritual renewal as much as the church; the church needs a social structure as much as the society. Therefore its task extends beyond its members to the broader public.

The public responsibility of the church has three aspects: (a) The leadership of the church at all levels must engage in the prophetic ministry, expose evil in society and demand redress. (b) The congregation must become a redemptive community, not only for its own members but also for its social environment. (c) The members of the church must act in responsibility before God in their secular professions and relationships. Luther insisted that we serve God not (only) as monks and nuns but also as politicians, mothers, policemen or artisans.

What is remarkable in all three aspects discussed so far is that divine action is mediated through human action. God's activity does not render human activity superfluous, but evokes, empowers and involves it. God's initiative does not smother our initiative but prompts it. God's responsibility does not obviate our responsibility but arouses it. This is not to be confused with the Pelagian idea of cooperation between God and humanity. Cooperation presupposes that we do our part of the job and God does his part. If that were the case, we would operate on the basis of our own strength, and God on the basis of his. Either of the partners could leave his/her part of the job undone. But then God would cease to be God and become one inner worldly agent or factor among others. And our responsibility would be limited and could be suspended. Whatever the merits of such an idea, it is not the biblical view.

The biblical concept of God says that nothing at all can exist or happen without God making it exist and happen - including our own existence and actions. God acts in and through us and the rest of creation, not apart from us. Therefore it is also not correct to say that we "surrender our wills" when we believe. On the contrary, our will is empowered by God's will. Only because God wills can we will. Only because God acts can we act. His action makes our action possible. In fact, God acts through our action. And the assurance that God acts is the most powerful motivation and inspiration for us to act. If God acts, he will succeed, so our action will not be in vain, although we may face frustrations on the way (1 Cor 15:58). The paramount example of God acting through a human being is Jesus Christ. And what happens in Christ is made present, accessible and effective here and now by the power of the Spirit. 
Focusing on the underlying delusion: hedonistic individualism

Concerning the prophetic ministry, the document addresses a level of the problem not often found in Christian statements on the subject:

The prophetic ministry has to expose and dismantle ideological smoke screens which cover up the pursuit of self-interest at the expense of others. Not so long ago it concentrated on the ideology and practice of apartheid. After apartheid a deeper and more universal level of collective selfishness must be exposed and attacked. It is the hedonistic culture of modernity, propagated by the advertising and entertainment industries for the sake of turnover and profit. The entertainment and advertising industries have billions of dollars at their disposal. The employ the best brains, the deepest psychology, the most sophisticated technology, the most powerful mass media. ${ }^{6}$ The feeble preaching of the church on Sunday mornings is no match for this massive onslaught.

Hedonism accords prime value to individual pleasure. From earliest childhood we are bombarded with the message that every individual is entitled to the immediate and total satisfaction of all his/her whims and desires. Please yourself, and never mind the consequences! All natural inhibitions, all religious taboos, all cultural values are deliberately and systematically undermined. If you want money, you go and get it. If you want sex, you go and get it. If you want to be "smart", you smoke and drink. If you want a high, you take drugs. If violence excites you, you play computer games, join a gang, or assault a family member. Excitement sells, sex sells, violence sells. Most of us have bought into this mentality in one way or another. It has entrenched itself in the new human rights culture which we have been yearning and fighting for. All individuals now seem to have the right to consider all options, take any kind of decision, and expose themselves and others to any risk. Detrimental behaviour is shielded from being exposed and overcome by the right to privacy. Public scrutiny is stifled. Morality is paralysed.

Lest we sound alarmist, let us look at some evidence. A study in an American city, a country where the hedonistic culture has had its most profound impact, showed that only $8 \%$ of all heterosexual men had a single life time partner, almost half had between 2 and 10 partners, and a further third had between 11 and 50 partners. There were no homosexuals who stuck to one partner and $75 \%$ had over 50 partners. During the three decades of the "sexual revolution" the instances of syphilis jumped from about 5000 in 1960 to over 35000 in 1990, a sevenfold increase... At the same time drug abuse has spiralled... Sexual lust also became more violent. An example is the growing popularity of "fisting", where a clenched fist is thrust up the anus into the rectum of a partner ... causing major injuries (Root-Bernstein 1993:282, 287, 295).

It is obvious that this explosion of uninhibited lust has an immediate bearing on the AIDS crisis. In Southern Africa other factors have reinforced this worldwide trend: the

6. "Advertisers in the corporate world are of course offered lucrative recompense, and, with that financial draw, our corporations attract humans from the highest strata of IQs. And our best artistic talent. And any sports hero or movie star they want to buy. Combining so much brain power and social status with sophisticated electronic graphics and the most penetrating psychological techniques, these teams of highly intelligent adults descend upon all of us, even upon children not yet in school, with the simple desire to create in us a dissatisfaction for our lives and a craving for yet another consumer product..." (Brian Swimme 1996. The hidden heart of the cosmos: Humanity and the new story. Maryknoll: Orbis, 16ff.) Among theologians who have gone public concerning the responsibility of advertisers and money spinners is Christ Chatteris (The Natal Witness 15 May 2001, p 8). He compares the habit forming deception that it is smart to smoke (the Marlboro Man) with the habit forming deception that promiscuity is cool (the Madonna syndrome). 
migrant labour system, chaotic urbanisation, the erosion of traditional values, mass impoverishment, national and continental migration, wars leading to ever new waves of refugees, and so on.

But the perception that we are entitled to the satisfaction of all our selfish desires, regardless of the consequences, does not only lead to the spread of HIV infection. It progressively undermines the marriage, dissolves the extended family, leaves the young generation without role models, and leads to juvenile delinquency, domestic violence, alcoholism, and drug abuse. The same mentality which makes parents die of AIDS also destroys extended family structures which constitute the only safety net for AIDS orphans. It is an unmitigated disaster. The church should say so loudly and clearly, and suggest alternatives. We must rediscover the rationale of sex as the celebration of a mature relationship between two loving partners, which finds expression in the life long commitment of a marriage, and which provides a "nest" for the young generation. The stable family is indispensable for children to develop their full potential and become free and responsible adults.

Moreover, the African concept of ubuntu could bring us back to our senses. It says that a person is a person only through other persons. There can be no individual rights at the expense of the community. In traditional African cultures sexual activity was confined to institutionalised relationships; promiscuity was virtually non-existent; social networks prevented people from exploiting each other for selfish gain. But traditional cultures also exacerbate the problem through male conceptions of virility; patriarchal dominance; female dependency; ascribing calamities to witchcraft; unscientific diagnoses and inappropriate prescriptions by diviners and healers; secrecy and taboos concerning sex education, and so on. Even ubuntu can be corrupted by selfishness in disguise... But freedom without responsibility is dangerous. In this case it is fatal.

The rapid spread of HIV/AIDS is thus seen by the document as a symptom of a much wider calamity - the same calamity that makes a person commit a murder to obtain a cell phone, that motivates a person to rape a child, that causes those who can least afford it to waste their meagre incomes on the national lottery, that allows loan sharks to ruin the lives of those who painted themselves into a financial corner. It is remarkable how the issue of basic values and simple decency is skirted even by the most proficient academics and the most highly placed bureaucrats. That everybody has an unalienable right to uninhibited sexual gratification is simply taken for granted, although its horrendous social consequences are there for all to see. ${ }^{7}$ Church leaders could overcome dogmatic hang-ups,

7. Peter Piot (op cit) begins bravely: "But this is not a security threat we are powerless to prevent. The epidemic is not inevitable: we know how to reduce the spread and HIV and to alleviate the epidemic's impact." But when it comes to "What can be done?" he offers nothing but generalities: the need for multisectoral responses, AIDS as a national priority, strengthening social inclusion, building stronger coping mechanisms, international solidarity, replacement of depleted resources, building partnerships in the response. All very true but void of contents! -- Similarly in his excellent work on auto-immune diseases, William R Clark speaks of the opportunities opened up by the rapidity of cultural evolution to "outwit rapidly evolving pathogens" through "behavioral modification" and "self-imposed behavioral changes" (op cit 173). But he never dares to spell out what such behavioral changes might be and on which cultural assumptions they might be based. -Equally vague is the Anglican document on AIDS: "We believe that we are given the freedom to make choices, to love, to celebrate, to live in dignity and to delight in God's creation ... Because we love our children, we speak and act to protect them from infection... We are accountable to God and one another for our sexual behaviour. Christians have a special responsibility and capacity for encouraging and supporting loving, just, honest relationships ... we commit to speak openly and with moral authority about responsible sexual behaviour and to support one another, embracing and adopting behaviours that avoid the transmission 
traditional prudishness and toothless moralising and come up with serious and hard-hitting social prophecy. ${ }^{8}$

Let us place this contention in the current debate. If the President believes that poverty is the prime cause of the pandemic, he may not be entirely off the track, except that it is a waste of time to debate the link between HIV and AIDS. But then we must ask the deeper question of what the prime cause of poverty is and how it can be overcome. ${ }^{9}$ Similarly, the document would agree with Evangelicals that ethical disorientation will lead us into "mega trouble" ${ }^{10}$ But we have to find the root cause of this strangely modern phenomenon. And it is, of course, true that an idealistic ethics offers no guidance in a sea of cultural anomie and social decay, that we need to make a "reality check" of the measures advocated, that "people will continue to have sexual relations that we may not approve of", that we are living in "a war zone" where "the key issue is survival", as "enlightened" Christians who propagate the use of condoms among the youth argue. ${ }^{11}$ But that does not mean, and it was

of HIV" (Our Vision, our Hope. The first step all Africa Anglican AIDS Planning Workshop. Issued in Johannesburg by Tulleken \& Associates, August 2001). Fair enough, but what does this mean? -- The much maligned A Message of Hope from the Catholic Bishops to the People of God in South Africa, Botswana and Swaziland" at least calls a spade a spade! Which does not mean that their dogmatically based rejection of condoms (and what they believe to be all artificial forms of contraception) can be condoned. There is indeed, as has been pointed out by so many critics, something like a "lesser evil". There is also something like Christian compassion. -- Some Catholic religious, of all people, have rightly maintained that we cannot simply let people die who are forced into unbearable situations or who have fallen. Not only sexuality, but life itself is sacred (Martin Badenhorst, Philippe Denis, Kees Keijsper, Munyaradzi Murove in The Natal Witness 16 Aug $2001 \mathrm{p} \mathrm{8)}$. While sexuality is meant to transmit life, condoms are a means to prevent the "transmission of death" (Bishop Dowling e-Praxis 8/2/01). -- Vusi Ngema, after spelling out "our daily dread" amongst the youth in KwaZulu-Natal - the uncertainty and anxiety that one may already be infected, the poisoning of relationships through suspicions, the deafening, terrifying silence which suddenly descends on a happy conversation, the venomous glee - comes up with the conclusion that "ironically, some of the most effective work around HIV/AIDS awareness is being conducted by "ordinary people" building on the so-called "backward culture practices" of abstinence and non-penetrative sex before marriage" (The Natal Witness, 25 Sept 2001, p 8).

8. In a hard-hitting article, which may overstate his point of hierarchical hypocrisy, Cosmas Desmond has this to say: "I would have thought that the selfish pursuit of wealth, consumerism, greed, and lack of concern for the poor were far more responsible for the decline of morals ... in our country" (Mail \& Guardian Vol 17, No 32, Aug 2001; Source: e-Praxis <teologie@ bigfoot.com> 8/11/01.)

9. Obviously this is a very complex issue which I have treated in great detail in my recent volume, Prosperity, Poverty and Pollution. Pietermaritzburg: Cluster Publications / London: Zed Books 1999.

10. "I believe that in South Africa our leaders and most of the rest of the nation are not only increasingly flying blind in a fog of ethical uncertainty, but we are perhaps beginning to fly upside down ... one cannot but realise that some of the wheels of our society are starting to fall off" (Michael Cassidy in Voice Mail, August 2001:7.

11. Phumele Ntombela-Nzimande in The Natal Witness, 21 August 2001, p 8. Similarly Archbishop Ndungane: "the church's calling (is) for people to abstain from sex or to be faithful ... but we realise that we live in a real world with human imperfection" (Source e-Praxis 8/17/01). --- Similarly Ron Nicolson: "AIDS is a pandemic in Southern Africa because too many people have too many partners ... If everyone lived as all the religions say they should - virgins before marriage, faithfulness after marriage - there would be no AIDS (but)... prohibiting condoms will not stop people having sex outside marriage ..." Nicolson supports the slogan "Give her love, not AIDS" and says that "sex with countless and nameless partners is not love" and "sex without love is demeaning, is less than truly human". He closes with the quotable words: "We can't legislate matters of love. But sooner rather than later, we need to remold sexual morality in South Africa away from a culture of instant gratification to one of responsibility, empathy and caring relationships. A condom culture does not help with that. Faced with the choice of death for thousands from AIDS and the death of responsible and caring sexuality, perhaps condoms are the lesser evil - but only just" (The Natal Witness 11 August 2001, p 6).--- Cedric Mayson tries to be even more realistic (and fatalistic?). "At one level it is simple: an irrational overwhelming instinct which perpetuates the species and does not give a damn about romance or love or responsibility. The sperm must be blasted into the egg and the future can look after itself. Like food and drink, sex demands self-gratification, but sex dresses its passion in romantic dreams and the music of emotion." Remove the romance and nothing is left but the copulation effect in dogs and cats; sex has become an end in 
never intended to mean by the authors quoted, that what could indeed serve as an emergency measure will be able to offer lasting solutions.

There are also conspicuous gaps in the document which need to be addressed. One of them is exactly the hotly debated issue of the free distribution of condoms among minor children. As the editor, I added a postscript saying:

The workshop did not deal with the question whether the Church should support the use of condoms. While Lutherans have no reason to oppose the use of condoms for family planning purposes, it was felt that the indiscriminate distribution of condoms by the

Church among the youth would send the wrong message and that the Church should devote itself to the much more difficult task of regaining and maintaining sexual discipline among youths and adults. However, Lutheran Ethics has always supported the principle of choosing the lesser evil and will not oppose the distribution of condoms where sexual discipline has collapsed.

To this must be added the all important gender issue. Women are more affected by the pandemic, patriarchal attitudes and female subjugation hugely exacerbate the problem, domestic violence and the pervasive occurrence of rape have become a scourge of immense proportions. ${ }^{12}$ The document also does not address another hotly debated issue, namely the provision of anti-retroviral drugs by the Government. When the document was drawn up, this issue had not yet attracted the overwhelming attention it enjoys now. Suffice it to say that Lutherans have no reason to argue against any remedy which offers redress or relief in desperate situations - a judgment which medical experts have to make - and should be encouraged to join lobbies which press for the release of the appropriate funds and the training of staff to achieve these ends. However, again they would caution against concentrating on consequences and symptoms rather than the cause of the calamity.

\section{The practical programme}

Agencies and actions

Coming to the programme itself, the document takes a radical position: a top down approach is bound to fail. The establishment of a grand bureaucracy with big budgets for salaries, cars and computers will not make a dent in the problem. Initiatives must be taken at grass roots community level.

It is recognised that, if this venture is to have a meaningful impact, structures and agencies must be formed in every parish or congregation. It is suggested that voluntary Parish AIDS Committees be formed which consist, as far as they are available, of a pastor, a doctor or nurse, a social worker, a youth leader and a person living with AIDS. Their brief would be: ...

- to act as resource groups for the congregation and the entire community,

- to draw up action plans together with the wider community,

- to set up an AIDS Support Group for each infected individual and affected family,

itself and "this is the type of sex encouraged by the beat and bang of so much modern music, the in thing which the media says you must buy as one of the major globalised industries." It is "in this situation of instant irresponsible gratification that most church leaders ... advocate condoms." Mayson believes that "under the frenetic pace and noise with which modern capitalistic culture is destroying humanity" a "renaissance of being human" might be born ("Pulpits and sex" e-Praxis 4/28/01). Well, precisely!

12. Charlene Smith 2001. Proud of me: Speaking out against sexual violence and HIV. London: Penguin. See also the article of Ntombela-Nzimande quoted above. 
- to monitor the situation of the orphaned and widowed and report back to the congregational leadership.

At circuit/district level there should be small AIDS Teams whose prime duties would be to encourage and monitor developments at parish levels within their respective realms. A similar team should operate at diocesan or church council level to encourage and monitor developments in circuits... These teams should again be answerable to diocesan/church councils and synods, on whose agendas the programme should become a regular feature. The training institutions of the churches should include this issue in their curriculum. The bishops must drive the process... The women's, men's and youth leagues should equally be involved at their normal meetings and in their respective structures.

The document concludes:

For the programme to succeed it is of utmost importance (a) that all these structures do not develop unwieldy offices which depend on external donors, $(b)$ that the mandates of the Parish AIDS Committees and the AIDS Support Groups do not overburden their members, (c) that responsibility and care is located in families and communities, rather than institutions and bureaucracies. Essentially the programme should be based in families and communities, while the Parish Committees should provide education, guidance and support. Administration at higher levels should be confined to the absolute minimum.

I would like to add the immensely sensible idea of Margaret Legum that families that take up AIDS orphans should receive a basic income from the state. It would be part of a "Basic Citizen's Income" which would allow those who have no chance of ever getting a job a means to survive and send their children to school. It would obviate all bureaucracies which have proved to be cumbersome and incompetent in the distribution of development moneys. ${ }^{13}$

\section{Resource Material}

As mentioned above, Parish HIV/AIDS Committees should include a medical professional able to gather and interpret relevant medical information. This information should be integrated with issues of faith and morality contributed by the theologian. Because these ideals cannot be realised in all circumstances, it is important that Parish AIDS Committees be provided with - a simple guideline, - prepared course material which can be used as examples, - a more elaborate collection of material to fall back on. A small Expert Group in medicine, social work and theology should ... put together a package which they consider to be in line with our tradition and suitable for our purposes. Moreover, a constant stream of information and motivation must be fed into the Parish AIDS Committees, the AIDS Support Groups, and through them into the parishes. This can perhaps be achieved through a short but flashy newsletter which concentrates on inspiring examples and which is sent out together with other regular circulars, such as Church Council minutes.

The document spells out the agendas and priorities of Parish AIDS Committees in some detail and a definite time frame. Mindful of the danger of bureaucratic procrastination, it concludes:

A famous pioneer of Lutheran social initiatives, Friedrich von Bodelschwingh, once said: "Don't take time - they are dying!"

13. Source: e-Praxis 4/17/01. 


\section{The impact of the document}

To my embarrassment I have to say that so far the exercise has proved to be a waste of time and funds. According to the proposed time frame the basic structure should have been in place by the end of 2000. Parish AIDS Committees should have identified all known cases, and established Support Groups for these cases, by the end of 2001. At the time of writing (January 2002) nothing had come of that. The LUCSA council of bishops appears to have accepted the proposals at the time, but months after the event bishops and pastors I have asked about its progress could not remember that such a document existed. At synods which I was privileged to attend, the issue of HIV/AIDS was either not raised or new appeals and suggestions were agreed upon. Dioceses, which had embarked on HIV/AIDS programmes, had done so without reference to the document or coordinating them with those of others. The warning not to concentrate on bureaucratic structures was not heeded either. Pastors are being swamped with burials of young people, but the underlying causes do not seem to be addressed.

In short, the workshop shared the much bewailed fate of all conferences. At a much publicised "Poverty Summit", where much money was spent by habitual conference trotters, including myself, at a posh venue to talk about the poor, and where the poor themselves were conspicuous by their absence, a prominent church leader said in his opening address: "We must go beyond words, words, words..." When the conference was over, I found a note somebody had scribbled on a piece of paper lying on his desk: "We went beyond words, words, words - to tea!" This indictment applies to me as to everybody else. I am very good at analysing and theologising, but that is where my competence and my commitment end. At least this insight is a valid outcome of the exercise.

But I would not bother to offer this essay to a wider audience if I was not convinced that the theological reflections and the practical suggestions were valid, and that they could make a substantial contribution to the gradually deepening recognition of Christians that they are faced with a challenge of immense proportions which none of us will be able to escape in the long run. Sometimes a seed sown takes time to germinate and, God willing, it may still grow into an impressive tree. (After the completion of this essay a workshop for church leaders on HIV/AIDS was organised by LUCSA. Hopefully this will take us a step further.) 


\section{BIBLIOGRAPHY}

Annan, Kofi 1999. UN AIDS Speeches. Geneva: UN Press Release.

Bartholet, J 2000. The plague years. Newsweek Jan 17, 2000, pp 6-17. (Powerful report on AIDS in Africa.)

Crowther, CE 1991. AIDS: A Christian handbook. London: Epworth Press. (A passionate plea for a loving and caring attitude towards AIDS sufferers.)

Geballe, S, Gruendel, J and Andiman, W 1995. Forgotten children of the AIDS epidemic. New Haven / London: Yale University Press. (Focus on the plight of infected and affected children.)

Lachmann, Sydney 1995. Heterosexual HIV/AIDS as a global problem. Braamfontein: TPS Drug Information Centre. (An exhaustive source of information on all aspects of AIDS from the pen of a South African expert. There is a follow-up volume called Towards 2000.)

Muir, MA 1991. The environmental contexts of AIDS. New York: Praeger.

Nicholson, R 1995. AIDS: A Christian response. Pietermaritzburg: Cluster Publications. (A very useful introduction to the problem and a Christian response.)

Overberg, KR 1994. AIDS, ethics and religion: Embracing a world of suffering. Maryknoll NY: Orbis Books. (A Catholic contribution to the debate.)

Root-Bernstein, RS 1993. Rethinking AIDS. New York: Free Press. (An attempt to place the disease into its greater medical and social contexts.)

Saayman, W and Kriel, J 1992. AIDS: The leprosy of our time? Johannesburg: Orion. (An early but still useful introduction, with a follow up in Missionalia vol 27/1999, pp 208ff.)

Shilts, Randy, 1987/8. And the band played on. London: Penguin. (A heart rending and detailed depiction of the situation in the USA from the pen of a person who died of AIDS.)

UNAIDS (no date). Force for Change - World AIDS Campaign with Young People. Geneva: UNAIDS. Website: www.UNAIDS.org

Whiteside, Alan 1998. Implications of AIDS for demography and policy in Southern Africa. Pietermaritzburg: University of Natal Press. 